\title{
PENENTUAN ASAM OKSALAT SECARA SPEKTROFOTOMETRI DENGAN METODE METILEN BIRU
}

\author{
Irmanto, Suyata \\ Jurusan Kimia, Program Sarjana MIPA Unsoed Purwokerto
}

\begin{abstract}
A spectrophotometric method for the determination of oxalic acid has been developed, based on its catalytic effect on the redox reaction between methylene blue and sulphide, measured at the maximum absorption wavelength of $664 \mathrm{~nm}$. Under the optimum conditions of $3 \mathrm{~mL}$ of $31 \%$ formaldehyde; $0.8 \mathrm{~mL}$ of $0,067 \mathrm{M}$ EDTA Triethanolamine; $1.2 \mathrm{~mL}$ of $0,010 \mathrm{M}$ sulphide; $2 \mathrm{~mL}$ of $0,0010 \%$ methylene blue at $20{ }^{\circ} \mathrm{C}$ for 1 minute a detection limit of $0,43 \mu \mathrm{g} / \mathrm{mL}$ for oxalic acid determination was obtained. This method can be applied to determination of trace level of oxalic acid
\end{abstract}

Keywords : spectrophotometry, oxalic acid, methylene blue, sulphide

\section{PENDAHULUAN}

Pertumbuhan penduduk yang semakin meningkat, menuntut adanya perbaikan kondisi kesehatan dan kehidupan terutama kebutuhan akan makanan. Untuk memenuhi tujuan ini berbagai jenis bahan kimia harus diproduksi dan digunakan, banyak diantaranya dalam jumLah yang besar. Salah satu contoh bahan kimia yang biasanya terkandung dalam produk makanan yaitu asam-asam organik.

Asam-asam organik pada umumnya merupakan turunan dari asam karboksilat. Asam-asam ini dapat membentuk garam dengan unsur-unsur logam dan mudah dijumpai. Salah satu contoh turunan asam karboksilat adalah asam oksalat. Asam oksalat merupakan asam organik kuat dengan nilai $\mathrm{pKa}$ sebesar 1,3 dan 4,3. Molekul asam oksalat terdiri atas dua gugus karboksil yang saling terikat sehingga lebih dikenal dengan nama asam dikarboksilat. Senyawa ini banyak ditemukan sebagai garam asam dalam berbagai tanaman yang berasa asam. Asam oksalat dapat mengganggu lapisan usus apabila dikonsumsi dan dapat berakibat fatal jika berada dalam dosis yang tinggi. Asam oksalat dapat bergabung dengan logam seperti kalsium di dalam tubuh untuk membentuk kristal oksalat yang dapat mengganggu usus dan ginjal. Mengikat gizi vital seperti kalsium, konsumsi jangka panjang makanan yang mengandung kadar asam oksalat tinggi dapat menyebabkan kekurangan gizi (Anonim,2005).

Asam oksalat banyak dihasilkan oleh tanaman dan hewan. Tidak seperti hewan, tanaman mempunyai toleransi tinggi terhadap asam oksalat. Asam oksalat telah dideteksi dalam jumLah yang bervariasi pada seluruh bagian tanaman seperti pada daun, tangkai daun, bunga, umbi dan akar. Salah satu contoh tanaman yang dapat menghasilkan asam oksalat adalah bayam. Konsentrasi oksalat tertinggi pada umumnya ditemukan pada bagian daun, sedangkan konsentrasi terendah ditemukan dalam akar. Oksalat terjadi secara alami di tanaman. Terbentuknya senyawa ini disebabkan oleh bergabungnya asam oksalat dengan kalsium, besi, sodium, magnesium serta kalium untuk membentuk sedikit garam dapat larut 
yang terdapat dalam tanaman (Caliskan, 2000).

Kandungan asam oksalat yang terdapat dalam tanaman, misalnya bayam, banyak sekali kegunaannya. Diantaranya dapat menurunkan kadar kolesterol, mencegah sakit gusi, mengobati eksim, asma, untuk perawatan kulit muka, kulit kepala dan rambut. Selain itu asam oksalat dapat mengobati rasa lesu dan kurang gairah akibat kurang darah. Disamping berfungsi dalam bidang kesehatan, asam oksalat juga dapat digunakan untuk keperluan yang lain. Penggunaan asam oksalat yang lebih dikenal yaitu sebagai pemutih kayu (Anonim,2005).

Asam oksalat selain mempunyai banyak kegunaan, juga dapat menyebabkan toksik bagi tubuh apabila dikonsumsi dalam jumLah atau kadar yang tinggi. Menurut Jiang et al. (1996), kandungan oksalat yang tinggi dalam urin atau komponen darah dapat menyebabkan penyakit ginjal, kekurangan vitamin, penyakit usus dan hiperoksaluria. Terbentuknya kristal oksalat pada tanaman atau sayuran akan menyebabkan penyakit batu ginjal apabila sayuran tersebut dikonsumsi oleh manusia secara berlebihan. Oleh karena itu metode yang tepat untuk penentuan asam oksalat sangat diperlukan.

Berbagai metode penelitian tentang asam oksalat telah dilakukan. Diantaranya menggunakan metode HighPerformance Liquid Chromathographic (HPLC) (Wu et al., 1998), dengan kromatografi ion eksklusi (Yang et al.,2000), dengan kromatografi gas (Ohkawa,1985), dan dengan Atom Absorption Spectroscopy

(AAS)

(Menache,1974). Namun, metode-metode yang pernah dilakukan ini memiliki kelemahan, yaitu tingkat sensitivitas metode yang rendah. Jiang et al.(1996) telah mengusulkan suatu metode spektrofotometri kinetik katalitik untuk penentuan asam oksalat berdasarkan efek katalitik asam oksalat pada reaksi redoks di antara kalium dikromat dan rodamin B.

Metode metilen biru telah digunakan untuk penentuan selenium (Se) berdasarkan efek katalitik selenium pada reaksi redoks antara metilen biru dengan sulfida dengan standar deviasi relatif 2,8\% ( $\mathrm{n}=16)$ (Bernal et al., 1990). Atas dasar inilah, akan dilakukan penelitian untuk penentuan asam oksalat berdasarkan efek katalitik asam oksalat pada reaksi redoks antara metilen biru dengan sulfida.

Metode metilen biru digunakan untuk analisis suatu reaksi berdasarkan efek katalitiknya pada reaksi redoks dan telah banyak digunakan di berbagai bidang untuk analisis pada tingkat konsentrasi runut (trace) karena sensitivitasnya yang sangat tinggi dan batas deteksinya yang rendah (Bernal et $a l .$, 1990). Penelitian ini dilakukan untuk menentukan kondisi optimum analisis yang meliputi konsentrasi reagen, temperatur dan waktu reaksi.

\section{METODE PENELITIAN Bahan dan Alat}

Bahan yang digunakan dalam penelitian ini adalah formaldehid, EDTA dalam trietanolamin, sulfida, asam oksalat, metilen biru, $\mathrm{CuCl}, \mathrm{ZnCl}_{2}, \mathrm{SnCl}_{2}$ dan akuades.

Alat yang digunakan dalam penelitian ini adalah satu unit spektrofotometer UV-Visible, neraca analitik, water bath thermostate, stop watch, dan alat-alat gelas

\section{Prosedur Kerja}

\section{Penentuan Konsentrasi Optimum Formaldehid (Bernal et al., 1990)}

Ke dalam labu ukur $10 \mathrm{~mL}$ ditambahkan $3 \mathrm{~mL}$ formaldehid dengan konsentrasi $29 \%$; $0,8 \mathrm{~mL}$ EDTAtrietanolamin $0,067 \mathrm{M} ; 1,2 \mathrm{~mL}$ sulfida $0,01 \mathrm{M} ; 2 \mathrm{~mL}$ asam oksalat $5 \mu \mathrm{g} / \mathrm{mL}$ dan $2 \mathrm{~mL}$ metilen biru $0,001 \%$, diencerkan dengan akuades sampai tanda batas. 
Campuran tersebut dimasukkan dalam water bath thermostate pada suhu $15{ }^{\circ} \mathrm{C}$ selama 1 menit. Setelah itu diukur absorbansinya pada panjang gelombang maksimum. Dengan cara yang sama, ditentukan absorbansi larutan dengan konsentrasi formaldehid dari $31 \%-37 \%$ dengan interval 2.

\section{Penentuan Konsentrasi Optimum EDTA-trietanolamin (Bernal et al., 1990)}

Ke dalam labu ukur $10 \mathrm{~mL}$ ditambahkan $3 \mathrm{~mL}$ formaldehid dengan konsentrasi optimum; 0,8 mL EDTAtrietanolamin $0,063 \mathrm{M} ; 1,2 \mathrm{~mL}$ sulfida $0,01 \mathrm{M} ; 2 \mathrm{~mL}$ asam oksalat $5 \mu \mathrm{g} / \mathrm{mL}$ dan $2 \mathrm{~mL}$ metilen biru $0,001 \%$, diencerkan dengan akuades sampai tanda batas dan dimasukkan dalam water bath thermostate pada suhu $15{ }^{0} \mathrm{C}$ selama 1 menit. Kemudian campuran tersebut diukur absorbansinya pada panjang gelombang maksimum. Dengan cara yang yang sama, diukur serapan larutan dengan konsentrasi EDTA-trietanolamin dari $0,065-0,071 \mathrm{M}$ dengan interval 0,002 .

\section{Penentuan Konsentrasi Optimum Sulfida (Bernal et al., 1990)}

Ke dalam labu ukur $10 \mathrm{~mL}$ ditambahkan $3 \mathrm{~mL}$ formaldehid dengan konsentrasi optimum; 0,8 mL EDTAtrietanolamin dengan konsentrasi optimum; 1,2 $\mathrm{mL}$ sulfida dengan konsentrasi $6 \times 10^{-3} \mathrm{M} ; 2 \mathrm{~mL}$ asam oksalat $5 \mu \mathrm{g} / \mathrm{mL}$ dan $2 \mathrm{~mL}$ metilen biru $0,001 \%$, diencerkan dengan akuades sampai tanda batas dan dimasukkan dalam water bath thermostate pada suhu $15{ }^{0} \mathrm{C}$ selama 1 menit. Setelah itu campuran diukur absorbansinya pada panjang gelombang maksimum. Dengan cara yang sama, diukur serapan larutan dengan konsentrasi larutan sulfid $8 \times 10^{-3}$ $-1,4 \times 10^{-2} \mathrm{M}$ dengan interval 0,002.

\section{Penentuan Konsentrasi Optimum Metilen Biru (Bernal et al., 1990)}

Ke dalam labu ukur $10 \mathrm{~mL}$ ditambahkan $3 \mathrm{~mL}$ formaldehid dengan konsentrasi optimum; 0,8 mL EDTAtrietanolamin dengan konsentrasi optimum; 1,2 $\mathrm{mL}$ sulfida dengan konsentrasi optimum; $2 \mathrm{~mL}$ asam oksalat $5 \mu \mathrm{g} / \mathrm{mL}$ dan $2 \mathrm{~mL}$ metilen biru dengan konsentrasi $6 \times 10^{-4} \%$, diencerkan dengan akuades sampai tanda batas dan dimasukkan dalam water bath thermostate pada $15{ }^{0} \mathrm{C}$ selama 1 menit. Kemudian campuran tersebut diukur absorbansinya pada panjang gelombang maksimum. Dengan cara yang sama, ditentukan absorbansi larutan dengan variasi konsentrasi metilen biru $8 \times 10^{-4}$ $\%$ - 1,4 x $10^{-3} \%$ dengan interval 0,0002 .

\section{Penentuan Temperatur Reaksi Optimum (Bernal et al., 1990)}

$\mathrm{Ke}$ dalam labu ukur $10 \mathrm{~mL}$ ditambahkan $3 \mathrm{~mL}$ formaldehid dengan konsentrasi optimum; 0,8 mL EDTAtrietanolamin dengan konsentrasi optimum; 1,2 $\mathrm{mL}$ sulfida dengan konsentrasi optimum; $2 \mathrm{~mL}$ asam oksalat dengan konsentrasi $5 \mu \mathrm{g} / \mathrm{mL}$ dan $2 \mathrm{~mL}$ metilen biru dengan konsentrasi optimum, diencerkan dengan akuades sampai tanda batas. Campuran larutan tersebut dimasukkan ke dalam water bath thermostate pada suhu $10{ }^{0} \mathrm{C}$ selama 1 menit. Setelah itu campuran diukur absorbansinya pada panjang gelombang maksimum. Dengan cara yang sama, diukur serapan larutan dengan variasi temperatur reaksi $15{ }^{\circ} \mathrm{C}$ sampai dengan $30{ }^{\circ} \mathrm{C}$.

\section{Penentuan Waktu Reaksi Optimum} (Bernal et al., 1990)

$\mathrm{Ke}$ dalam labu ukur $10 \mathrm{~mL}$ ditambahkan $3 \mathrm{~mL}$ formaldehid dengan konsentrasi optimum; 0,8 mL EDTAtrietanolamin dengan konsentrasi optimum; 1,2 $\mathrm{mL}$ sulfida dengan konsentrasi optimum; $2 \mathrm{~mL}$ asam oksalat dengan konsentrasi $5 \mu \mathrm{g} / \mathrm{mL}$ dan $2 \mathrm{~mL}$ metilen biru dengan konsentrasi optimum, diencerkan dengan akuades sampai tanda batas. Campuran larutan tersebut dimasukkan ke dalam water bath thermostate pada temperatur reaksi 
optimum selama 0,5 menit. Setelah itu campuran diukur absorbansinya pada panjang gelombang maksimum. Dengan cara yang sama, diukur serapan larutan dengan variasi waktu reaksi $1-2$ menit.

\section{Pengaruh Ion Logam Lain (Bernal et al., 1990)}

Pengaruh ion logam dapat dipelajari dengan menganalisa larutan standar yang mengandung asam oksalat 5 $\mu \mathrm{g} / \mathrm{mL}$ dan ion-ion logam tunggal (yaitu : $\mathrm{Cu}, \mathrm{Sn}, \mathrm{Zn})$ yang divariasikan dari 10 $\mu \mathrm{g} / \mathrm{mL}$ sampai $50 \mu \mathrm{g} / \mathrm{mL}$. Ke dalam labu ukur $\quad 10 \mathrm{~mL}$ ditambahkan $3 \mathrm{~mL}$ formaldehid dengan konsentrasi optimum; 0,8 mL EDTA-trietanolamin dengan konsentrasi optimum; 1,2 mL sulfida dengan konsentrasi optimum; asam oksalat dan ion logam dengan perbandingan volume $1: 1$; dan $2 \mathrm{~mL}$ metilen biru dengan konsentrasi optimum, diencerkan dengan akuades sampai tanda batas dan dimasukkan dalam water bath thermostate pada temperatur reaksi optimum selama waktu reaksi optimum. Kemudian campuran diukur absorbansinya pada panjang gelombang maksimum. Respon sinyal dari larutan yang mengandung masingmasing ion logam tersebut dibandingkan dengan suatu larutan kontrol yang tidak mengandung ion logam.

\section{HASIL DAN PEMBAHASAN}

Zat warna metilen biru biasanya digunakan sebagai pereaksi analitik dalam analisis spektrofotometri dan spektrofluorometri. Baru-baru ini metilen biru telah dipakai untuk penentuan selenium (Bernal et al., 1990). Pada penelitian ini, metode metilen biru dikembangkan untuk penentuan asam oksalat berdasarkan efek katalitiknya pada reaksi redoks antara metilen biru dengan sulfida.

Reaksi redoks antara metilen biru dengan sulfida berlangsung sangat lambat tanpa kehadiran suatu katalis , persamaan reaksinya adalah sebagai berikut:

$$
2 \mathrm{MB}+\mathrm{S}^{2-}+\mathrm{H}_{2} \mathrm{O} \rightarrow 2 \mathrm{HMB}+2 \mathrm{OH}^{-}+\mathrm{S}
$$

Ketika penambahan sulfida terjadi secara berlebihan, maka akan diperoleh sulfur, kemudian sulfur ini dilarutkan untuk membentuk polisulfida :

$$
S+S^{2-} \rightarrow[S \ldots S]^{2-}
$$

Dengan kehadiran asam oksalat sebagai katalis, maka akan membentuk komplek :

$$
\left[\mathrm{S}_{\ldots} . \mathrm{C}_{2} \mathrm{H}_{2} \mathrm{O}_{4}\right]^{2-}
$$

sehingga reaksi yang terjadi secara keseluruhan sebagai berikut :

$2 \mathrm{MB}+\left[\mathrm{S}_{\ldots} \mathrm{C}_{2} \mathrm{H}_{2} \mathrm{O}_{4}\right]^{2-}+2 \mathrm{H}_{2} \mathrm{O} \rightarrow 2 \mathrm{HMB}+2 \mathrm{OH}^{-}+\mathrm{S}+\mathrm{C}_{2} \mathrm{H}_{2} \mathrm{O}_{4}$ Reaksi ini berjalan lebih cepat dengan adanya katalis asam oksalat dibandingkan dengan reaksi tanpa katalis asam oksalat (Bernal et al., 1990). Suatu katalis diduga mempengaruhi kecepatan reaksi dengan salah satu jalan : (1) dengan pembentukan senyawa antara (katalis homogen) atau (2) dengan adsorpsi (katalis heterogen) (Keenan, dkk, 1984). Katalis asam oksalat dalam reaksi redoks antara metilen biru dengan sulfid mempengaruhi kecepatan reaksi dengan pembentukan senyawa antara (komplek intermediat) yaitu $\left[\mathrm{S}_{\ldots} . \mathrm{C}_{2} \mathrm{H}_{2} \mathrm{O}_{4}\right]^{2-}$, kemudian kompleks intermediat ini akan bereaksi dengan metilen biru dalam pelarut air $\left(\mathrm{H}_{2} \mathrm{O}\right)$ sehingga akan menghasilkan suatu produk akhir reaksi dimana katalis asam oksalat akan terpisah dari rantai reaksi (Bernal et al., 1990).

Laju suatu reaksi dapat dinyatakan sebagai laju berkurangnya konsentrasi suatu pereaksi, atau sebagai laju bertambahnya konsentrasi suatu produk (Keenan, dkk, 1984) sehingga pengaruh konsentrasi dari formaldehid, sulfida, EDTA-trietanolamin dan metilen biru terhadap nilai absorbansi dipelajari untuk menentukan kondisi optimum dari variable-variabel ini.

\section{Penentuan Panjang Gelombang Maksimum}

Panjang gelombang maksimum dapat ditentukan dengan mengukur absorbansi dari larutan metilen biru 
$0,001 \%$ pada panjang gelombang dari 600-660 nm. Berdasarkan kurva hasil pengukuran dimana absorbansi sebagai sumbu Y dan panjang gelombang sebagai sumbu $X$ diperoleh hasil seperti yang ditunjukkan pada Gambar 1.

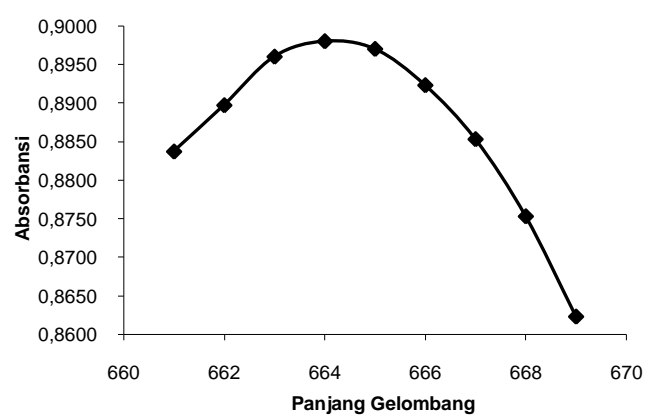

Gambar 1. Kurva panjang gelombang Metilen Biru.

Berdasarkan hasil yang ditunjukkan pada Gambar 1 dapat dilihat bahwa absorbansi maksimum metilen biru diperoleh pada panjang gelombang $664 \mathrm{~nm}$, sehingga panjang gelombang ini digunakan untuk memonitor reaksi (Bernal et al., 1990).

\section{Penentuan Konsentrasi Optimum Formaldehid}

Hubungan diantara absorbansi (A) dan konsentrasi formaldehid dipelajari dengan memvariasikan konsentrasi formaldehid pada range konsentrasi $29 \%$ sampai $37 \%$. Hasil yang diperoleh seperti yang ditunjukkan pada Gambar 2.

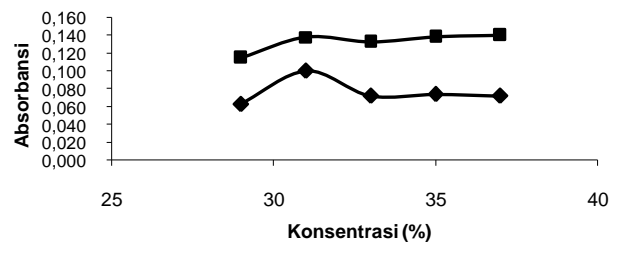

Gambar 2. Pengaruh konsentrasi

formaldehid. $(\bullet)$ Sistem dikatalis oleh $5 \mu \mathrm{g} / \mathrm{mL}$ asam oksalat. (匹) Sistem yang tidak dikatalis.
Pengaruh konsentrasi formaldehid terhadap nilai absorbansi seperti yang terlihat pada Gambar 2 menunjukkan absorbansi yang bertambah dengan bertambahnya konsentrasi formaldehid sampai mencapai konsentrasi $31 \%$ dan pada konsentrasi yang lebih tinggi terjadi penurunan absorbansi. Oleh karena itu, $31 \%$ dipilih sebagai konsentrasi optimum dari formaldehid untuk penentuan asam oksalat.

\section{Penentuan Konsentrasi Optimum EDTA-Trietanolamin}

Pengaruh konsentrasi EDTAtrietanolamin terhadap nilai absorbansi dapat dipelajari dengan memvariasikan konsentrasi EDTA-trietanolamin pada range konsentrasi $0,063 \mathrm{M}$ sampai 0,071 M. Hasil yang diperoleh seperti terlihat pada Gambar 3.

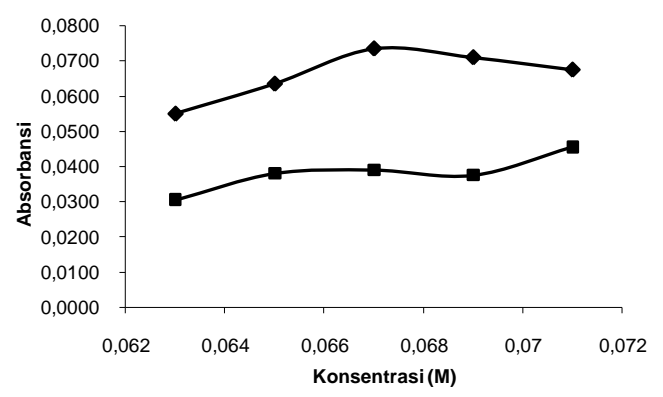

Gambar 3. Pengaruh konsentrasi EDTA-

Trietanolamin. ( ) Sistem dikatalis oleh $5 \mu \mathrm{g} / \mathrm{mL}$ asam oksalat.

Sistem yang tidak dikatalis.

Berdasarkan hasil yang ditunjukkan pada Gambar 3 dapat dilihat bahwa nilai absorbansi bertambah dengan bertambahnya konsentrasi EDTAtrietanolamin pada variasi konsentrasi dari $0,063 \mathrm{M}$ sampai $0,067 \mathrm{M}$ dan pada konsentrasi EDTA-trietanolamin yang lebih tinggi terjadi penurunan nilai absorbansi. Oleh karena itu, 0,067 M dipilih sebagai konsentrasi optimum dari EDTA-trietanolamin.

Nilai absorbansi dari sistem yang dikatalis oleh asam oksalat lebih besar dari nilai absorbansi dari sistem yang tidak dikatalis. Hal ini menunjukkan 
bahwa kecepatan reaksi reduksi metilen biru oleh sulfida meningkat dengan penambahan katalis asam oksalat.

\section{Penentuan Konsentrasi Optimum Sulfida}

Hubungan diantara absorbansi dan konsentrasi sulfida dipelajari dengan memvariasikan konsentrasi sulfida pada range konsentrasi $6 \times 10^{-3} \mathrm{M}$ sampai $1,4 \mathrm{x}$ $10^{-2} \mathrm{M}$. Hasil yang diperoleh seperti yang ditunjukkan pada Gambar 4.

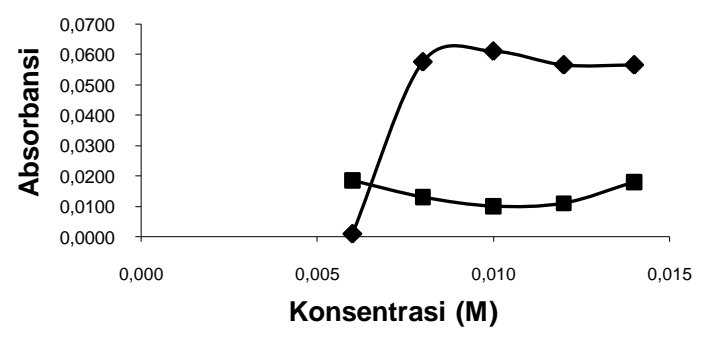

Gambar 4. Pengaruh konsentrasi sulfida

( ) Sistemd ikatalis oleh $5 \mu \mathrm{g} / \mathrm{mL}$ asam oksalat.(匹) Sistem yang tidak dikatalis.

Pengaruh konsentrasi sulfida terhadap nilai absorbansi seperti yang terlihat pada Gambar 4 menunjukkan nilai absorbansi bertambah dengan bertambahnya konsentrasi sulfida sampai mencapai konsentrasi $0,010 \mathrm{M}$ dan pada konsentrasi yang lebih tinggi terjadi penurunan nilai absorbansi. Oleh karena itu, 0,010 M dipilih sebagai konsentrasi optimum dari larutan sulfid.

\section{Penentuan Konsentrasi Optimum Metilen Biru}

Pengaruh konsentrasi metilen biru terhadap nilai absorbansi dipelajari dengan memvariasikan konsentrasi metilen biru dari $0,0006 \%$ sampai $1,4 \mathrm{x}$ $10^{-3} \%$ seperti dapat dilihat pada Gambar 5.

Berdasarkan hasil yang ditunjukkan pada Gambar 5 dapat dilihat bahwa nilai absorbansi dari sistem yang dikatalis oleh $5 \mu \mathrm{g} / \mathrm{mL}$ asam oksalat bertambah dengan bertambahnya konsentrasi asam oksalat sampai mencapai konsentrasi $0,0010 \%$ dan pada konsentrasi yang lebih tinggi terjadi penurunan. Oleh karena itu, 0,0010\% dipilih sebagai konsentrasi optimum dari metilen biru untuk penentuan asam oksalat.

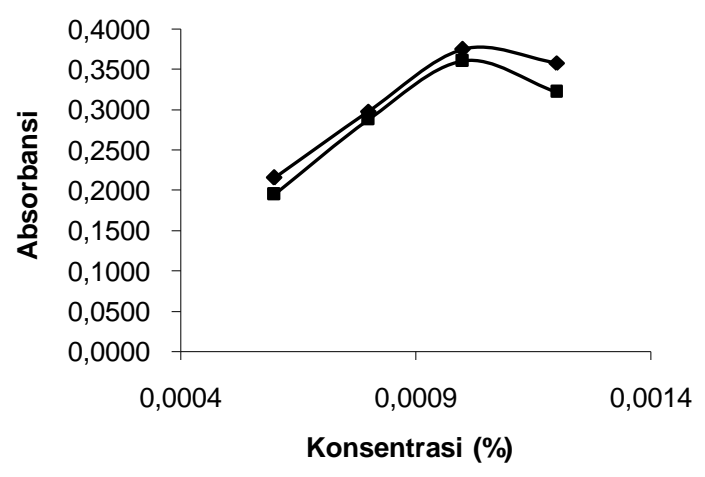

Gambar 5. Pengaruh konsentrasi metilen biru. ( ) Sistem dikatalis oleh $5 \mu \mathrm{g} / \mathrm{mL}$ asam oksalat. Sistem yang tidak dikatalis.

\section{Penentuan Temperatur Reaksi Optimum}

Temperatur reaksi memainkan peranan penting dalam sistem reaksi. Pengaruh temperatur reaksi pada reaksi redoks antara metilen biru dengan sulfida ini dipelajari dengan memvariasikan temperatur dari $10{ }^{0} \mathrm{C}$ sampai $30{ }^{0} \mathrm{C}$ seperti terlihat pada Gambar 6.

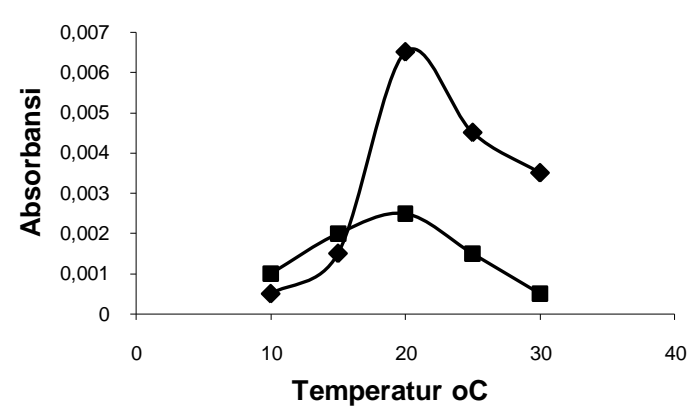

Gambar 6. Pengaruh temperatur reaksi ( ) Sistem dikatalis oleh 5 $\mu \mathrm{g} / \mathrm{mL}$ asam oksalat. (口) Sistem yang tidak dikatalis. 
Berdasarkan hasil yang ditunjukkan pada Gambar 6 dapat dilihat bahwa kecepatan reaksi bertambah dengan meningkatnya temperatur reaksi, dan nilai absorbansi dari sistem yang dikatalis oleh asam oksalat terjadi penurunan pada temperatur $25{ }^{\circ} \mathrm{C}$. Oleh karena itu, $20{ }^{\circ} \mathrm{C}$ dipilih sebagai temperatur reaksi optimum.

Nilai absorbansi dari sistem yang dikatalis oleh asam oksalat lebih besar dari nilai absorbansi dari sistem yang tidak dikatalis. Hal ini menunjukkan bahwa reaksi redoks diantara sulfida dan metilen biru dapat dipercepat dengan meningkatkan temperatur reaksi dan penambahan asam oksalat sebagai katalis.

\section{Penentuan Waktu Reaksi Optimum}

Metode waktu reaksi tertentu digunakan untuk memonitor reaksi redoks antara metilen biru dengan sulfida (Bernal et al., 1990). Lamanya reaksi redoks ini berlangsung pada konsentrasi dan temperatur reaksi optimum dipelajari dengan melihat pengaruh waktu reaksi pada range 0,$5 ; 1$; dan 1,5 menit seperti ditunjukkan pada Gambar 7.

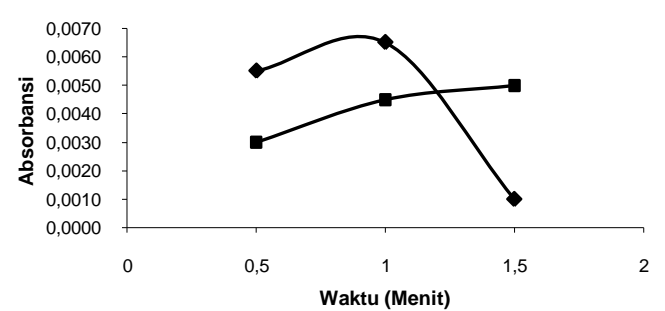

Gambar 7. Pengaruh waktu reaksi.( Sistem dikatalis oleh 5 $\mu \mathrm{g} / \mathrm{mL}$ asam oksalat. (ロ Sistem yang tidak dikatalis.

Berdasarkan hasil yang ditunjukkan pada Gambar 7 dapat dilihat bahwa kecepatan reaksi bertambah dengan meningkatnya waktu reaksi, dan absorbansi dari sistem yang dikatalis oleh asam oksalat meningkat pada waktu reaksi 1 menit dan pada waktu yang lebih tinggi absorbansinya menurun. Oleh karena itu, 1 menit dipilih sebagai waktu reaksi optimum.

\section{Penentuan Kurva Kalibrasi}

Kurva kalibrasi ditentukan di bawah kondisi optimum, hubungan diantara absorbansi dan konsentrasi asam oksalat dipelajari dengan memvariasikan konsentrasi asam oksalat pada variasi konsentrasi $1,2,3,4,5 \mu \mathrm{g} / \mathrm{mL}$. Kurva kalibrasi standar asam oksalat dapat dilihat pada Gambar 8.

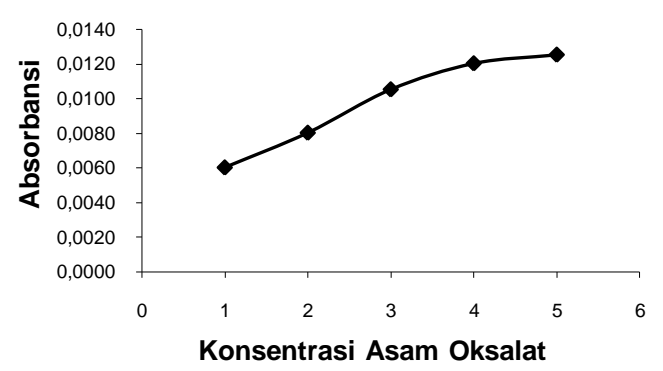

Gambar 8. Kurva Kalibrasi Asam Oksalat $(\mu \mathrm{g} / \mathrm{mL})$

Gambar 8. memperlihatkan bahwa kurva kalibrasi linier pada variasi konsentrasi asam oksalat sampai $4 \mu \mathrm{g} / \mathrm{mL}$ dengan persamaan regresi $\mathrm{y}=4 \cdot 10^{-3}+2,05 \cdot 10^{-3} \mathrm{x}$. Koefisien korelasi $(r)$ yang diperoleh dari metode ini sebesar 0,9958. Menurut Miller dan Miller (1991), bahwa $r$ dapat mempunyai nilai dalam rentang $-1 \leq r \leq 1$, sehingga nilai koefisien korelasi $(r)$ yang diperoleh ini sebaik nilai yang telah diusulkan.

Nilai $r=-1$ menggambarkan korelasi negatif sempurna, yaitu semua titik percobaan terletak pada garis lurus yang negatif lerengnya. Demikian pula, bila $r=+1$ kita memperoleh korelasi positif sempurna, semua titik tepat terletak pada garis lurus yang positif lerengnya. Bila tidak ada korelasi antara $\mathrm{x}$ dan $\mathrm{y}$, maka nilai $r$ sama dengan nol (Miller dan Miller, 1991).

\section{Penentuan Batas Deteksi}

Menurut Miller, 1991, untuk menentukan batas deteksi diperlukan data slope kurva kalibrasi (b) dan standar deviasi blanko, $S_{\mathrm{y} / \mathrm{x}} \quad\left(\mathrm{S}_{\mathrm{B}}\right)$ dari larutan standar dengan persamaan : 


$$
\text { Batas Deteksi }(B D)=\frac{3 S_{B}}{b}
$$

Batas deteksi yang diperoleh berdasarkan persamaan di atas sebesar $0,43 \mu \mathrm{g} / \mathrm{mL}$. Hal ini menunjukkan bahwa konsentrasi terendah yang dapat diukur oleh alat untuk sampel asam oksalat adalah 0,43 $\mu \mathrm{g} / \mathrm{mL}$.

Standar deviasi relatif yang diperoleh untuk penentuan $3 \mu \mathrm{g} / \mathrm{mL}$ asam oksalat $(\mathrm{n}=6)$ adalah 5,6 \%. Standar deviasi relatif atau disebut juga coefficien of variation (C.V.) menunjukkan keragaman data. Semakin besar nilai koefisien variansi maka data semakin bervariasi, sehingga keragaman data semakin tinggi (Skoog, 1991).

\section{Penentuan Sensitivitas Metode}

Sensitivitasmetode

spektrofotometri didefinisikan sebagai harga konsentrasi dari unsur dalam larutan (dalam mikrogram per $\mathrm{mL}$ atau dalam ppm) yang menghasilkan serapan sinar pancaran sebesar $99 \%$ atau serapan 0,0044 (Buchari, 1990 dalam Hartati et al., 1999). Dengan menggunakan rumus :

$$
S=\frac{0,0044}{b}
$$

kemudian dengan memasukkan harga $b$ (slope kurva kalibrasi) $=2,05.10^{-3}$ diperoleh harga sensitivitas metode sebesar 2,146 $\mu \mathrm{g} / \mathrm{mL}$. Nilai ini berarti bahwa konsentrasi larutan sampel yang memberikan sinar transmitans $99 \%$ atau serapan 0,0044 adalah pada konsentrasi $2,146 \mu \mathrm{g} / \mathrm{mL}$. Sensitivitas suatu metode analisis sangat tergantung pada banyak faktor, diantaranya adalah jenis metode analisis, dan tipe peralatan yang digunakan serta kegunaan hasil analisisnya (Nur dan Adijuwana, 1989).

\section{Pengaruh Ion Logam Lain}

Pengaruh ion-ion logam ini pada penentuan asam oksalat dapat dilihat pada Gambar 9.

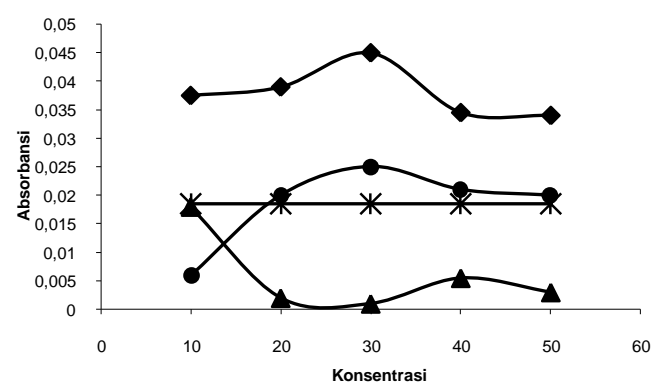

Gambar 9. Pengaruh ion logam lain. ( $)$ ion logam $\mathrm{Cu} .(\bullet)$ ion logam Zn. (ム) ion logam Sn. (*) Larutan kontrol.

Berdasarkan Gambar 9 dapat dilihat bahwa pada konsentrasi $10 \mu \mathrm{g} / \mathrm{mL}$ ion logam $\mathrm{Cu}$ memberikan interferensi negatif dimana ion logam $\mathrm{Cu}$ meningkatkan serapan larutan $(0,0375)$. Sedangkan ion logam $\mathrm{Zn}$ menurunkan serapan larutan (0,006). Hal ini disebabkan karena ion logam tersebut ikut mengkatalis reaksi redoks antara metilen biru dengan sulfida sehingga memberikan interferensi positif (Bernal et al., 1990). Ion logam Sn pada konsentrasi $10 \mu \mathrm{g} / \mathrm{mL}$ tidak memberikan pengaruhnya karena nilai absorbansi (serapan) yang diperoleh sama dengan serapan larutan kontrol.

Ion - ion logam $\mathrm{Cu}$ dan $\mathrm{Zn}$ pada konsentrasi $20 \mu \mathrm{g} / \mathrm{mL} \quad-50 \mu \mathrm{g} / \mathrm{mL}$ memberikan interferensi negatif dimana ion-ion logam tersebut meningkatkan serapan larutan seperti terlihat pada Gambar 9. Sedangkan untuk ion logam Sn pada konsentrasi $20 \mu \mathrm{g} / \mathrm{mL}$ - 50 $\mu \mathrm{g} / \mathrm{mL}$ memberikan interferensi positif karena ion logam tersebut ikut mengkatalis reaksi redoks antara metilen biru dengan sulfida sehingga menurunkan serapan larutan. Gangguan dari ion-ion logam dapat dihilangkan dengan menambahkan zat penutup (masking agent) seperti EDTA (Skoog, 1991). 


\section{KESIMPULAN}

Metode ini dapat digunakan untuk penentuan asam oksalat pada tingkat konsentrasi runut dengan kondisi optimum analisis adalah $3 \mathrm{~mL}$ formaldehid $31 \%$; $0,8 \mathrm{~mL}$ EDTATrietanolamin $0,067 \mathrm{M} ; 1,2 \mathrm{~mL}$ sulfida 0,010 M; $2 \mathrm{~mL}$ metilen biru 0,0010\%; temperatur reaksi $20{ }^{\circ} \mathrm{C}$ dan waktu reaksi 1 menit.

Batas deteksi dari metode ini adalah $0,43 \mu \mathrm{g} / \mathrm{mL}$ dan standar deviasi relatif untuk penentuan $3 \mu \mathrm{g} / \mathrm{mL}$ asam oksalat adalah 5,6 \%. Sedangkan sensitivitas metode yang diperoleh adalah $2,146 \mu \mathrm{g} / \mathrm{mL}$.

\section{UCAPAN TERIMA KASIH}

Penulis mengucapkan terima kasih yang sebesar-besarnya kepada Ketua Jurusan Kimia Unsoed atas kepercayaan dan pemberian dananya. Kepala Laboratorium Kimia Analitik, Analis laboratorium Kimia Analitik serta saudara Wijayanti yang telah membantu penelitian ini.

\section{DAFTAR PUSTAKA}

Anonim, 2005, Oxalic acid, (on-line), http:/en.wikipedia.org

/wiki/oxalic acid diakses tanggal 25 Oktober 2005.

Anonim, 2006, Katalis, (on-line), http://id.wikipedia.org/wiki/Katalis diakses tanggal 31 Mei 2006.

Bernal, J.L., M.J. Nozal, L. Deban, and F.J. Gomez, 1990, Modification of The Methylene Blue method For Spectrophotometric Selenium Determination, Talanta, 37 : 931936.

Caliskan, M., 2000, The Metabolism of Oxalic Acid, Turk J Zool, Vol 24 : 103-106.
Hartati, M., dan R.S.Pradipto, 1999, Penentuan Tembaga secara Spektrofotometri Sebagai senyawa Kompleks Asosiasi Ion dengan Metilen Biru melalui Ekstraksi Pelarut, Jurnal MIPA Universitas Airlangga, 2 : 135-139.

Jiang, Z.L., M.X.Zhao, and L.X.Liao, 1996, Catalytic Spectrophotometric Methods For Determination of Oxalic Acid, Analytical Chimica Acta, 320 : 139-143.

Keenan, C.W, Kleinfelter, D.C, Wood, J.H, Pudjaatmaka, A.H., 1990, Ilmu Kimia Untuk Universitas, Edisi Keenam, Jilid 1, Erlangga, Jakarta.

Menache. R., 1974, Routine Micromethod For Determination of Oxalic Acid in Urine by Atomic Absorption Spectrophotometry, Clinical Chemistry. 20:1444-1445. (on-line),

http://www.clinchem.org/cgi/conten t/abstract/20/11/1444 diakses tanggal 17 April 2006.

Miller,J.C. dan Miller, J.N., 1991, Statistik Untuk Kimia Analitik. Penerbit ITB, Bandung.

Nur, M.A, dan H. Adijuwana., 1989, Teknik Spektroskopi dalam Analisis Biologi, Penerbit ITB, Bogor.

Ohkawa,H., 1985, Gas Chromatographic Determination of Oxalic acid in Foods, J Assoc Off Anal Chem. 68(1):108-111, (on-line), http://www.ncbi.nlm. gov/entrez/query.fcgi?cmd=Retriev e\&db=PubMe\&list_uids=3980399 \&dopt $=$ Abstract diakses tanggal 17 April 2006. 
Skoog, A, 1991, Fundamental of Analytical Chemistry, $7^{\text {th }}$ Edition, Sounder College Publising, USA.

.Wu, Fengwu, Zhike HE, Qingyao, L, Yun'e, Z., 1998, High-Performance Liquid Chromatographic Determination of Oxalic Acid in Tea Using Tris(1,10-phenantroline)ruthenium(II) Chemiluminescence, Analytical Science, 14 : 971-973.

Yang, L., Liu, L., Olsen, B.A., Nussbaum., 2000, The Determination of Oxalic Acid, Oxamic Acid, and Oxamide in a Drug Substance by Ion-Exclusion Chromatography,Journal of Pharmaceutical and Biomedical Analysis. 20(3):487-493. (on-line). http://www.aapspharmaceutica.com /search/view.asp?ID=26537 diakses tanggal 17 April 2006. 